\title{
Resting stage abundance in the biogenic fraction of surface sediments from the deep Mediterranean Sea*
}

\author{
LUIGI DELLA TOMMASA ${ }^{1}$, ROBERTO DANOVARO², GENUARIO BELMONTE ${ }^{1}$ \\ and FERDINANDO BOERO ${ }^{1}$
}

${ }^{1}$ Di.S.Te.B.A., Università di Lecce. Complesso ECOTEKNE, 73100 Lecce, Italy. E-mail: genuario.belmonte@ unile.it

${ }^{2}$ Sezione Biologia Marina, Facoltà di Scienze, Università di Ancona, via Brecce Bianche, 60131 Ancona, Italy.

SUMMARY: The presence of resting stages in neritic areas is well known, while their occurrence in the deep sea realm has seldom been considered. Recent investigations showed strict interactions between neritic and deep sea domains, due to upand down-welling phenomena driven by submarine canyons. To estimate the presence of resting stages in deep bottom sediments, seven sediment cores, collected along a trans-Mediterranean transect by means a multi-corer during the TRANSMED survey (1999), were studied. Most biogenic sediment was composed of Foraminifera tests (tens of thousand tests $\mathrm{cm}^{-3}$ ), Calciodinellum albatrosianum and Leonella granifera (Dinophyta) cysts (up to thousands cysts $\mathrm{cm}^{-3}$ ). Eleven dinocyst morphotypes were recorded mainly as empty shells (seven calcareous-walled: $C$. albatrosianum, Calciperidinium asymmetricum, Leonella granifera, Scrippsiella trochoidea, S. precaria type 1, S. precaria type 2, S. regalis; four organicwalled: Impagidinium aculeatum, unid. dinocyst 1, unid. dinocyst 2 and unid. dinocyst 3), while no metazoan resting eggs were observed. The presence of viable resting stages in deep bottom surface sediments was much lower than in neritic areas, suggesting that oceanic species do not produce cysts for a "benthic resting" strategy. Further taxonomic and biogeographic studies are needed to better understand the ecological dynamics of oceanic plankton in the Mediterranean Sea.

Key words: resting stages, deep sea, Mediterranean, biogenic sediments, cyst morphology.

RESUMEN: ABUNDANCIA DE ESTADIOS QUIESCENTES EN LA FRACCIÓN BIOGÉNICA DE SEDIMENTOS SUPERFICIALES DEL MAR MEDITERRÁNEO PROFUNDO. - La presencia de estadios quiescentes en áreas neríticas es bien conocida, pero su presencia en fondos profundos raramente se considera. Investigaciones recientes han demostrado interacciones estrictas entre los ámbitos nerítico y profundo, debido a fenómenos de afloramiento y hundimiento mediados por los cañones submarinos. Para estimar la presencia de estadios quiescentes en sedimentos profundos se estudiaron siete testigos de sedimento, obtenidos durante el proyecto TRANSMED a lo largo de un transecto transmediterráneo. utilizando un tomatestigos múltiple. La mayor parte de sedimento biogénico estaba compuesto por caparazones de foraminíferos (decenas de miles de caparazones $\mathrm{cm}^{-3}$ ), cistes de Calciodinellum albatrosianum y Leonella granifera (Dinófitos; hasta miles de cistes $\mathrm{cm}^{-3}$ ). Se registraron once morfotipos de dinocistes principalmente como caparazones vacíos (siete con paredes calcáreas: C. albatrosianum, Calciperidinium asymmetricum, Leonella granifera, Scrippsiella trochoidea, S. precaria tipo 1, S. precaria tipo 2, S. regalis; cuatro con paredes orgánicas: Impagidinium aculeatum, dinociste no identificado 1, dinociste no id. 2 y dinociste no id. 3), mientras que no se observaron huevos de reposo de metazoos. La presencia de estadios quiescentes viables en sedimentos superficiales profundos fue mucho menor que en áreas neríticas, lo que sugiere que las especies oceánicas no producen cistes como estrategia "de quiescencia bentónica". Se precisan más estudios taxonómicos y biogeográficos para comprender mejor la dinámica ecológica del plancton oceánico en el mar Mediterráneo.

Palabras clave: estadios quiescentes, mar profundo, Mediterráneo, sedimentos biogénicos, morfología de cistes.

*Received September 19, 2001. Accepted January 20, 2003. 


\section{INTRODUCTION}

Dormancy is a common life cycle trait in marine plankton. Resting stages were recorded in crustaceans (Onbé, 1991; Mauchline, 1998), diatoms (Mc Quoid and Hobson, 1995, 1996), dinoflagellates (Wall and Dale, 1968; Bolch and Hallegraeff, 1990; Sonneman and Hill, 1997; Nehring, 1997) and tintinnids (Reid and John, 1978; Kamiyama, 1996).

Most ecological investigations on plankton organisms producing resting stages focused on neritic areas and dealt with taxonomy (Matsuoka, 1988; Lewis, 1991; Dale et al., 1993; Matsuoka and Cho, 2000), biogeography (Lindley, 1990; Nehring, 1997; Persson et al., 2000), toxic aspects related to harmful algal blooms (Han and Terazaki, 1993; Matsuoka and Fukuyo, 1994; Mackenzie et al., 1996; Ellegaard and Oshima, 1998; Dale et al., 1999), alien species invasions (Hallegraeff and Bolch, 1992; Carlton and Geller, 1993; Hallegraeff, 1998; Hamer et al., 2000), and population dynamics (Uye, 1985; Ishikawa and Taniguchi, 1996) of single taxa. The ecological role of resting stages in plankton-benthos coupling in coastal areas, already suggested by Dale (1983) for dinoflagellates and Uye (1985) for copepods, was recently considered as one of the most important keys to understand the dynamics of the whole plankton community (Boero, 1994; Boero et al., 1996). Marcus and Boero (1998) proposed a synthetic model (the "supply-vertical ecology") based on this generalised life cycle trait to better explain neritic plankton dynamics.

Recent micro-palaeontological studies focused on dinoflagellate resting stages on the surface sediments of deep waters for taxonomic as well as palaeo-climatic investigations (Zonneveld, 1995; Zonneveld and Brummer, 2000; Vink et al., 2000a; b; Meier, 2002). Nevertheless, due both to sampling difficulties and scant attention to the role of resting stages in the meiobenthic domain (Pati et al., 1999), the presence of cysts in deep sea bottoms has been seldom considered. Dale and Dale (1992) showed a high contribution of empty calcareous oceanic cysts (mostly Thoracosphaera $=$ Calciodinellum albatrosiana) to the biogenic portion in Atlantic and Pacific Ocean sediments. More recently, Della Tommasa et al. (2000) recorded a high concentration of resting stages (both Protoctista and Metazoa) in the Foix Canyon (NW Mediterranean, Spain), showing a storage effect by submarine canyons on coastal resting stage dynamics, driven by downwelling phenomena. The interactions between oceanographic
TABLE 1. - Surface sediment samples from the Mediterranean

\begin{tabular}{lccc}
\hline Station & Depht $(\mathrm{m})$ & Sampling date & Position \\
\hline S1 & -3870 & $8 / 6 / 99$ & $35^{\circ} 46.292^{\prime} \mathrm{N} ; 28^{\circ} 43.147^{\prime} \mathrm{E}$ \\
S2 & -3055 & $15 / 6 / 99$ & $33^{\circ} 23.176^{\prime} \mathrm{N} ; 28^{\circ} 19.042^{\prime} \mathrm{E}$ \\
S3 & -2950 & $16 / 6 / 99$ & $34^{\circ} 52.909^{\prime} \mathrm{N} ; 22^{\circ} 31.968^{\prime} \mathrm{E}$ \\
S4 & -4000 & $20 / 6 / 99$ & $35^{\circ} 37.181^{\prime} \mathrm{N} ; 17^{\circ} 23.370^{\prime} \mathrm{E}$ \\
S5 & -1290 & $23 / 6 / 99$ & $36^{\circ} 36.664^{\prime} \mathrm{N} ; 12^{\circ} 14.744^{\prime} \mathrm{E}$ \\
S6 & -2850 & $26 / 6 / 99$ & $38^{\circ} 24.046^{\prime} \mathrm{N} ; 06^{\circ} 53.721^{\prime} \mathrm{E}$ \\
S7 & -2755 & $1 / 7 / 99$ & $40^{\circ} 33.990^{\prime} \mathrm{N} ; 04^{\circ} 57.137^{\prime} \mathrm{E}$ \\
\hline
\end{tabular}

and life cycle patterns is a neglected field in marine ecology; the aim of present work is to evaluate the presence of plankton-originated resting stages on the surface of deep Mediterranean sediments to ascertain their possible role in plankton-benthos coupling in off-shore areas.

\section{MATERIAL AND METHODS}

Seven sediment cores, collected at seven stations (S1-S7) in summer 1999 along a horizontal transect from the Eastern to the Western Mediterranean (Fig. 1) by means of a multicorer (mod Maxicorer, i.d. 9.0 $\mathrm{cm}$, depth penetration $>20 \mathrm{~cm}$ ) during the TRANSMED survey, were analysed (Table 1). As described in recent literature (Zonneveld, 1997; Vink et al., 2000a,b; Meier et al., 2002), the uppermost centimeter of the cores was collected to study the most recent material. Each sample was washed with filtered seawater $(0.45 \mu \mathrm{m})$, ultrasonified for $3 \mathrm{~min}$ with a Branson Sonifier and sieved at three mesh sizes $(250 \mu \mathrm{m}, 63 \mu \mathrm{m}$, and $20 \mu \mathrm{m})$ with filtered seawater. Each sieve-fraction was diluted in $30 \mathrm{ml}$ of filtered seawater. The whole fraction $>250 \mu \mathrm{m}$, and $10 \%$ aliquots of the others $(250-63 \mu \mathrm{m}$, and $63-20 \mu \mathrm{m})$ were observed for each sample. Optimal aliquot size was calculated by a preliminary statistical analysis optimising subsampling according to Bros and Cowell (1987). The identification and the isolation of biogenic components from sediment were carried out with an inverted microscope at 50X and 200X connected to a digital video-camera. Resting stage (or "cyst", according to Belmonte et al., 1995) abundance was compared with that of other biogenic particles grouped according to two categories: Foraminifera tests, and "others" (comprising Mollusca shells, Radiolaria and Tintinnina loricas). Since this study focused on the near-surface layer $(0-1 \mathrm{~cm})$, no drying practices were carried out (Dale, 2001; Matsuoka, 2001), therefore the number of observed items was related to one $\mathrm{cm}^{3}$ of wet sediment. 


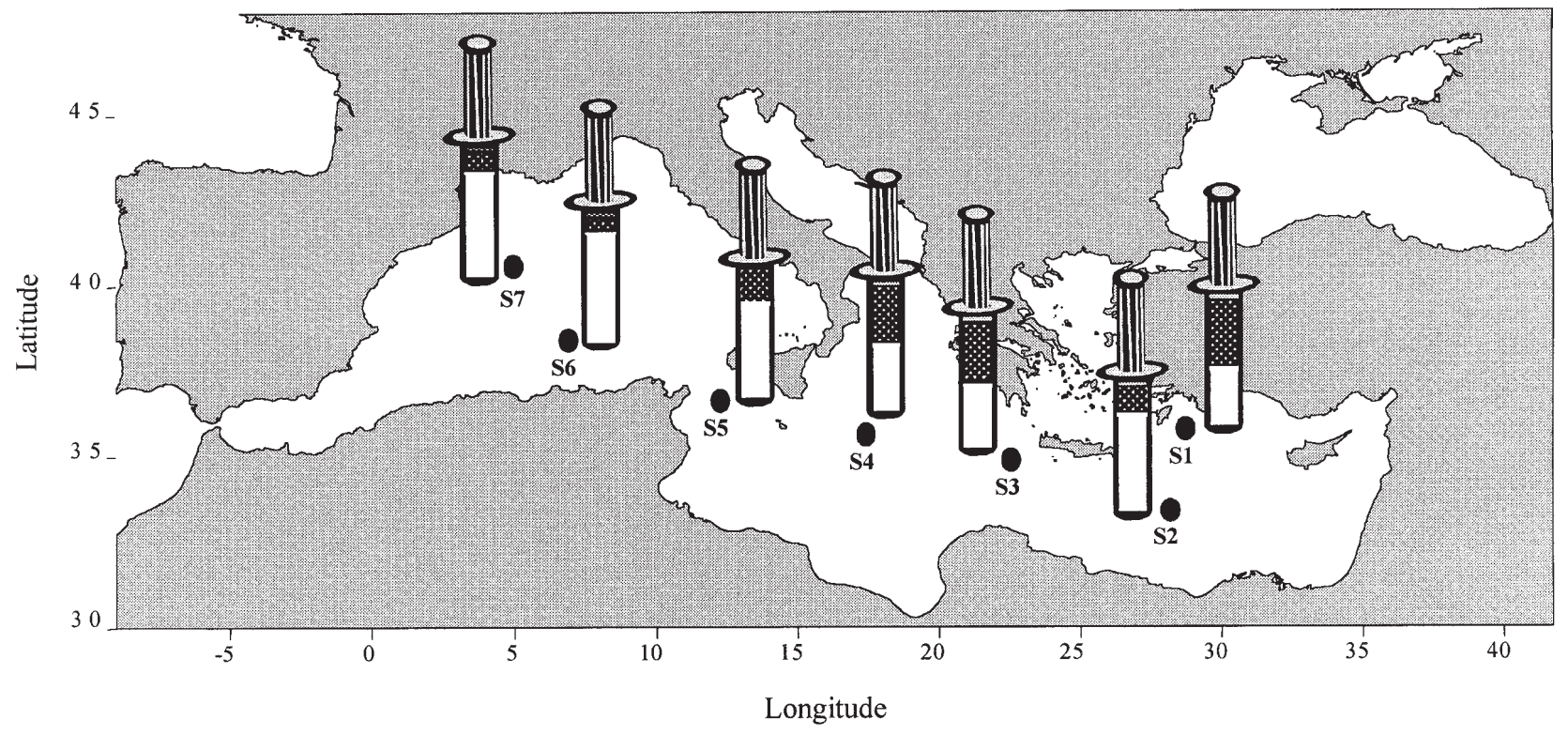

Foraminifera tests $\quad$ Cysts

FIG. 1. - Location of sampling stations in the Mediterranean Sea and percentage composition of the observed surface sediments.

\section{RESULTS}

\section{Biogenic sediment composition}

As shown in Figure 1 the relative abundance of Foraminifera tests varied from $43 \%$ (S1) to $85.6 \%$ (S6), representing the majority of recorded biogenic particles. Globigerina bulloides and Globorotalia scitula, found as both empty and full tests, were the most represented species (Table 2). The abundance of foraminiferan empty tests varied from 2,524 tests $\mathrm{cm}^{-3}$ (S4) to 27,039 tests $\mathrm{cm}^{-3}$ (S2), whereas full ones varied from 786 tests $\mathrm{cm}^{-3}(\mathrm{~S} 3)$ to 8,578 tests $\mathrm{cm}^{-3}$ (S2).

Also resting stages (cysts) were recorded as both full and empty. Their relative abundance was included between $10.8 \%$ in S6 and $54.3 \%$ in S1, mainly due to empty shells (most were Calciodinellum albatrosianum and Leonella granifera), that varied from 1,326 shells $\mathrm{cm}^{-3}$ (S6) to 16,600 shells $\mathrm{cm}^{-3}$ (S1). Full cysts ranged from 5 (S1) to 138 cysts $\mathrm{cm}^{-3}$ (S7). In S2 and S3 stations, viable (=full) cysts were not recorded. Finally, also the remaining categories (Mollusca, Radiolaria, and Tintinnina) were mostly recorded as empty shells. However, they represented a minority of biogenic particles, with a lower relative abundance than the previously considered categories (from $0.5 \%$ in S5 to $3.5 \%$ in S6) at all sampling stations.

\section{Resting stages (Fig. 2).}

Eleven dinoflagellate cyst morphotypes were found, while no metazoan resting eggs were recorded. Seven were calcareous cysts (Calciodinellum albatrosianum, Calciperidinium asymmetricum, Leonella granifera, Scrippsiella trochoidea, S. precaria type 1, S. precaria type 2, S. regalis) and four were organicwalled (Impagidinium aculeatum, unid. dinocyst 1, unid. dinocyst 2 and unid. dinocyst 3).

\section{Scrippsiella trochoidea (Fig. 2a)}

Size, without spines, $35 \mu \mathrm{m} \times 30 \mu \mathrm{m}$. Ovoidal, calcareous-walled, with pointed, pyramidal spines. Recorded (only as empty shell) from all stations, ranging from 1 cyst cm-3 in S3 to 60 cysts $\mathrm{cm}^{-3}$ in S2. This morphotype appeared more similar to the coastal Scrippsiella species (see S. trochoidea in: Sonnemann and Hill, 1997; Montresor et al., 1998; Lewis, 1991; Rubino et al., 2000; or Scrippsiella sp. 2 in Belmonte et al., 1995) than to the oceanic $S$. cf. trochoidea recorded by Dale and Dale (1992).

\section{Scrippsiella precaria}

(type 1, Fig. 2b; type 2, Fig. 2c)

Diameter, without spines, $25 \mu \mathrm{m}$ (Fig. 2b) and 27 $\mu \mathrm{m}$ (Fig. 2c). Two morphotypes of cysts were attrib- 


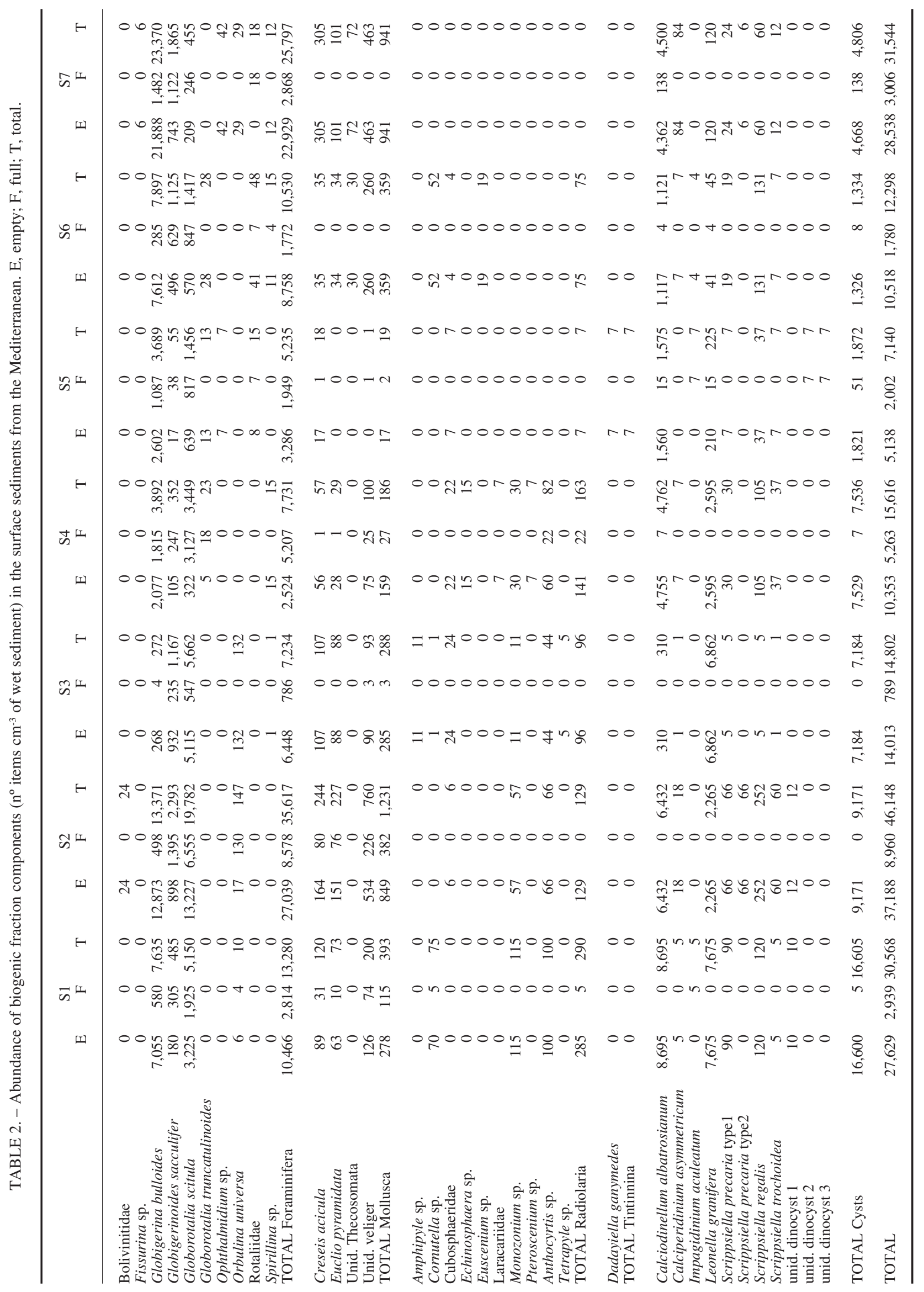



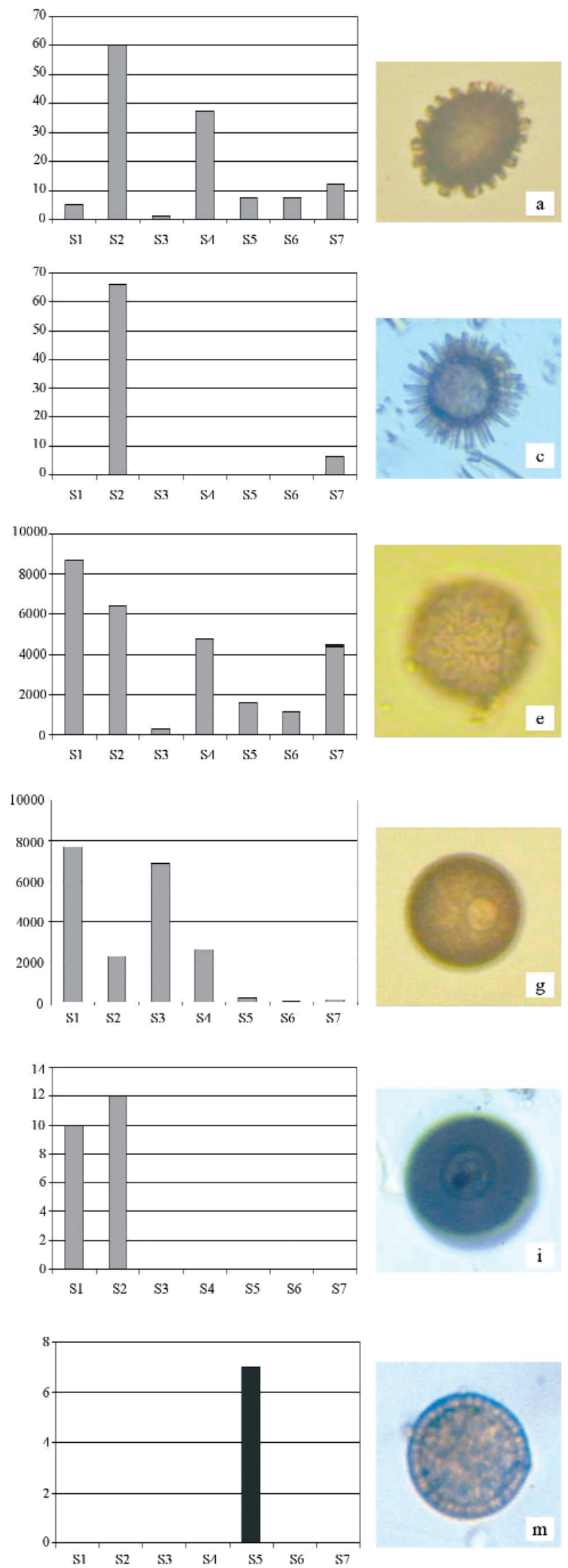
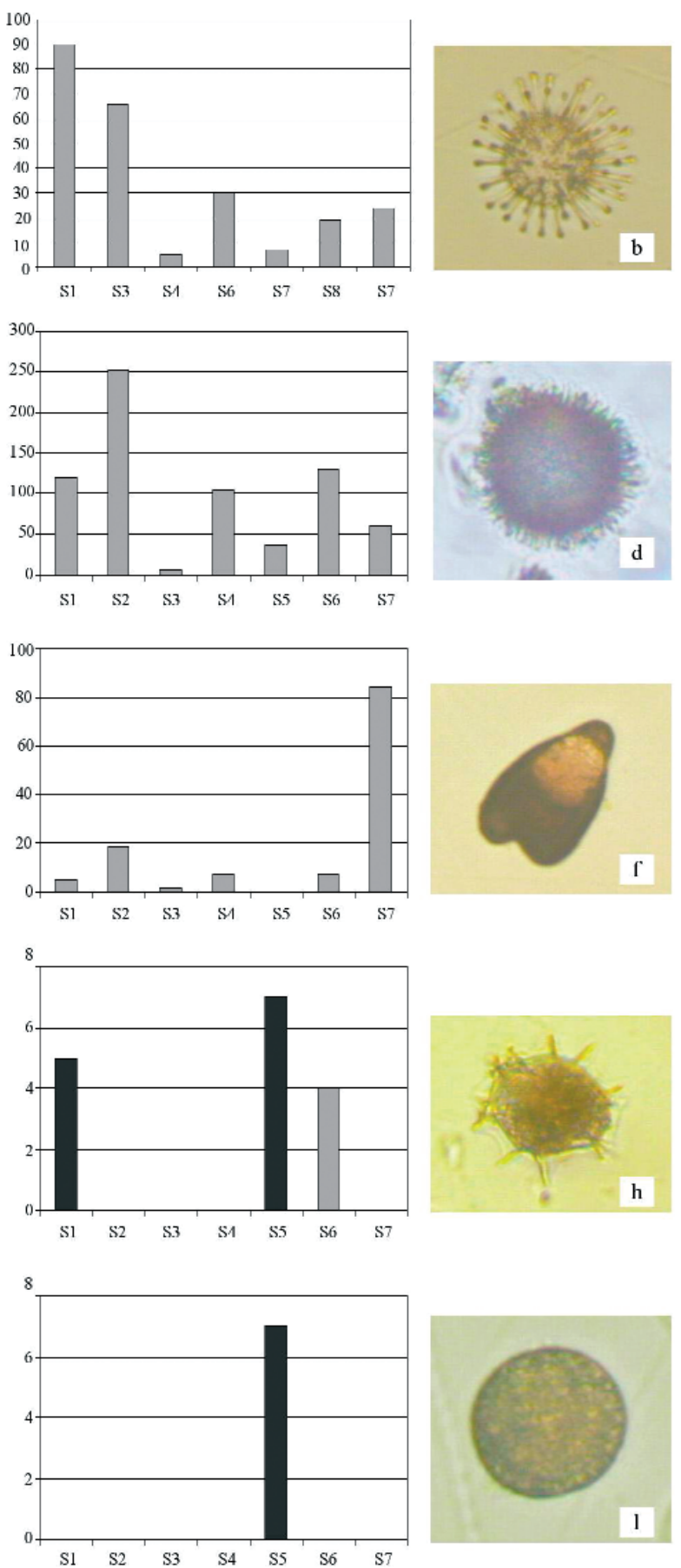

FIG. 2. - Abundance of cysts $\left(\mathrm{n}^{\mathrm{o}}\right.$ items $\mathrm{cm}^{-3}$ of wet sediment) in surface sediments from the Mediterranean stations S1-S7. a, Scrippsiella trochoidea; b, Scrippsiella precaria type 1; c, S. precaria type 2; d, Scrippsiella regalis; e, Calciodinellum albatrosianum; f, Calciperidinium asymmetricum; g, Leonella granifera; h, Impagidinium aculeatum; i, unid. dinocyst $1 ; 1$, unid. dinocyst 2; m, unid. dinocyst 3 . See text for details. 
uted to $S$. precaria as type 1 (with capitate spines) and type 2 (with pointed spines) respectively, this species being polymorphic (Montresor and Zingone, 1988). Type 1 was present at all stations (only as empty shells), ranging from 5 (S3) to 90 cysts $\mathrm{cm}^{-3}$ (S1). Type 2 was recorded (only as empty shells) at $\mathrm{S} 2\left(66\right.$ cysts $\left.\mathrm{cm}^{-3}\right)$ and $\mathrm{S} 7$ stations $\left(6\right.$ cysts $\left.\mathrm{cm}^{-3}\right)$.

\section{Scrippsiella regalis (Fig. 2d)}

Diameter, without spines, $44 \mu \mathrm{m}$. Spherical, with short pointed spines. Cyst morphology similar to that of $S$. trochoidea living in neritic areas (Janofske, 2000). Already recorded in the western equatorial Atlantic Ocean (Vink et al., 2000a), this species was present in all samples (only as empty shells), ranging from 5 (S5) to 252 cysts $\mathrm{cm}^{-3}$ (S2).

\section{Calciodinellum albatrosianum (Fig. 2e)}

Diameter, $25 \mu \mathrm{m}$. Spherical, calcareous-walled, surface scaled, archeopyle shape as described by Janofske and Karwath (2000). C. albatrosianum cysts have been recorded in equatorial Atlantic Ocean by Janofske and Karwath (2000); they have been also recorded as Thoracosphaera albatrosiana by Dale and Dale (1992) in Atlantic and Pacific deep areas and by Della Tommasa et al. (2000) in the Foix Canyon in NW Mediterranean. Vink et al. (2000a) recorded it (as Sphaerodinella? albatrosiana cysts) in the western equatorial Atlantic Ocean. In this study, C. albatrosianum was the most abundant recorded dinocyst. Empty cysts were present in all samples, varying from 310 (S3) to 8,695 cysts $\mathrm{cm}^{-3}(\mathrm{~S} 1)$. Full cysts were recorded only in the central and western Mediterranean sediments (from S4 to S7 samples), ranging from 4 (S6) to 138 cysts $\mathrm{cm}^{-3}$ (S7).

\section{Calciperidinium asymmetricum (Fig. 2f)}

Size, $62 \mu \mathrm{m}$ x $48 \mu \mathrm{m}$. Heart-shaped, bilobate antapex, calcareous-walled, trapezoidal archeopyle. Already recorded by Wall et al. (1973, pp. 2526, Pl. 1 Fig. 22) and Nehring (1997, type B, Fig. 35 , p. 320), this species has been described by Versteeg (1993) from the Upper Pleistocene fossil assemblages in the southern continental margin of Crete. In this study, $C$. asymmetricum was observed (only as empty shells) in all samples except in S6. Its abundance varied from 1 (S3) to 84 cysts $\mathrm{cm}^{-3}$ (S7).

\section{Leonella granifera (Fig. 2g)}

Diameter, $22 \mu \mathrm{m}$. Spherical, calcareous-walled, smooth surface, circular archeopyle as described by Janofske and Karwath (2000). L. granifera cysts have been recorded in plankton samples from the equatorial Atlantic Ocean (Kerntopf, 1997; Janofske and Karwath, 2000); they have been also recorded as Thoracosphaera granifera by Dale and Dale (1992) in sediment trap contents from the Atlantic and Pacific Oceans; Vink et al. (2000a) recorded them (as Orthopithonella? granifera) from the western equatorial Atlantic Ocean. In this study, L. granifera was the second most abundant dinocyst. Empty cysts were present in all samples, varying from 41 (S6) to 7,675 cysts $\mathrm{cm}^{-3}(\mathrm{~S} 1)$. Full cysts were recorded only in S4 and $\mathrm{S} 7$ samples (respectively 15 and 4 cysts $\mathrm{cm}^{-3}$ ).

\section{Impagidinium aculeatum (Fig. 2h)}

Size without crest, $30 \mu \mathrm{m}$ x $22 \mu \mathrm{m}$. Oval, organic-walled, crested surface. Impagidinium, typically described as a pelagic genus (Wall et al., 1977; Harland, 1983; Marret, 1994), was recently found also in shelfward areas in western Atlantic sediments (Vink et al., 2000b). In this study, Impagidinium aculeatum was recorded as both full cysts (5 cysts $\mathrm{cm}^{-3}$ in $\mathrm{S} 1$, and 7 cysts $\mathrm{cm}^{-3}$ in S5) and empty shells (4 cysts $\mathrm{cm}^{-3}$ in $\mathrm{S} 6$ ).

\section{Unidentified dinocyst 1 (Fig. 2i)}

Diameter, $52 \mu \mathrm{m}$. Spherical, smooth surface, organic-walled, round archeopyle. Paleontological studies include similar "round brown" cysts in the genus Brigantedinium (Vink et al., 2000b) but there are no records for cysts with a round archeopyle like that reported here. In this study the unid. dinocyst 1 has been recorded only from eastern Mediterranean sediments as empty shells (10 cysts $\mathrm{cm}^{-3}$ in $\mathrm{S} 1$, and 12 cysts $\mathrm{cm}^{-3}$ at $\mathrm{S} 2$ ).

\section{Unidentified dinocyst 2 (Fig. 2l)}

Diameter, $45 \mu \mathrm{m}$. Spherical, smooth surface, with a thin organic wall, brownish in colour. This morphotype has been recorded only at $\mathrm{S} 5$ as a full cyst $\left(7\right.$ cysts $\left.\mathrm{cm}^{-3}\right)$.

\section{Unidentified dinocyst 3 (Fig. 2m)}

Diameter, $28 \mu \mathrm{m}$. Spherical, smooth surface, 
with a thick organic wall, brownish in colour. This morphotype has been recorded only at S5 as a full cyst $\left(7\right.$ cysts $\left.\mathrm{cm}^{-3}\right)$.

\section{DISCUSSION}

Resting stages highly contributed (in terms of abundance) to the biogenic fraction of surface sediments from deep Mediterranean Sea that was dominated by Foraminifera tests. Resting stages were recorded only as dinocysts; neither metazoan nor ciliates cysts were observed. Eleven dinocyst morphotypes were found and most of them were empty. Therefore, the cyst contribution to Mediterranean deep areas, in terms of both diversity and viable cysts, was lower than to Mediterranean coastal areas (Montresor et al., 1998; Rubino et al., 2000). Nevertheless, recent investigations are increasing the number of recorded species in those deep areas: a taxonomic survey on calcareous dinoflagellates from Mediterranean sediments revealed 14 species including one new genus and four new species (Meier et al., 2002).

The low number of viable cysts recorded in this study confirmed previous observations carried out on surface sediments from the equatorial Atlantic Ocean (Vink et al., 2000a,b), Arabian Sea (Zonneveld, 1997), and on sediment trap contents from both Central Pacific and Central Atlantic Oceans (Dale \& Dale, 1992). Janofske and Karwath (2000) found viable cysts of the oceanic species $\mathrm{Cal}$ ciodinellum albatrosianum and Leonella granifera in plankton samples collected in the uppermost water layers. So that, as suggested by Dale and Dale (1992), the oceanic cysts should guarantee the species to have a buoyancy regulation mechanism to remain strategically placed in the water column.

Because of high distances from the bottom to the water surface, it should be difficult for a motile stage emerging from a cyst to reestablish contact with the plankton of upper layers; therefore, Dale and Dale (1992) hypothesized that the ecological role of cysts produced by oceanic species should not be considered in the framework of a "benthic resting" strategy. These suggestions seem to be confirmed by culture experiments carried out on oceanic species by Janofske and Karwath (2000) who showed that the obtained cysts were not hypnozygotes or resting cysts, being unconnected to a sexual phase. The estimated cyst sinking time (Anderson et al., 1985) should allow an oceanic specimen to encyst, fall to an optimal nutritionally richer water layer, and then excyst completing its life cycle in a few tens of meters. This would explain the high abundance of empty shells in the deep sea sediments as a by-product of dinoflagellates living in the upper waters.

In general, our data validated this hypothesis; nevertheless, full cysts of dinoflagellates classically considered as oceanic (I. aculeatum, C. albatrosianum, $L$. granifera) beside full cysts of unknown species (unid. dinocyst 2, unid. dinocyst 3) were found. As noted by Dale (1996) the cyst distribution in the deep sea bottom is broader than the distribution of the respective motile stages in the water column. Therefore, cyst assemblages found in the deep sea should derive from long distance transport rather than production from overlying surface waters (Dale, 1996; Dale and Dale, 1992). In such way, the ecological role of oceanic cysts as dispersal stages (Dale and Dale, 1992) would be fulfilled, and the few non-hatched cysts that fall to the bottom should be considered as a small investment of each species, akin to a bet-hedging strategy (Philippi and Seger, 1989), to be moved away by deep mixing currents. Moreover, a key role in cyst dispersal should be played by bottom geomorphology and water mass circulation at different scales. In fact, the evidence of high cyst diversity at some deep sites (e.g. submarine canyons, Della Tommasa et al., 2000) was attributed to particular geomorphological situations that improve the transport speed of cysts from (neritic) production areas to the storage (deep) ones.

In this study, four cyst morphotypes belonged to species tipically considered as oceanic $(C$. albatrosianum, L. granifera, I. aculeatum, Scrippsiella regalis); three ones to species tipically considered as coastal (Scrippsiella precaria type 1, S. precaria type 2, Scrippsiella trochoidea); and the remaining four ones (Calciperidinium asymmetricum, unid. dinocyst 1 , unid. dinocyst 2 , unid. dinocyst 3 ) with an unknown distribution. Most knowledge on oceanic cysts is based on morphological observation. Nevertheless, morphological differences between cysts do not reflect taxonomic differences. Polymorphic cysts belonging to the same species are very common (Lewis, 1991; Montresor and Zingone, 1988; Matsuoka and Cho, 2000). On the other hand, some convergences on cyst morphology have been recorded in dinoflagellate species (Matsuoka, 1988; Lewis, 1990; Harland, 1992; Janofske, 2000). The S. trochoidea cyst, here reported from surface sediments of deep Mediterranean Sea (Fig. 2a), is more similar to the coastal $S$. trochoidea than to the "oceanic" $S$. 
cf. trochoidea recorded by Dale and Dale (1992) from Pacific and Atlantic Oceans. Recently Janofske and Karwath (2000) clarified the taxonomy of $C$. albatrosianum and L. granifera until then considered as "calcispheres" (Dale and Dale, 1992; Janofske, 1996; Kerntopf, 1997).

Life cycle investigations could clarify the role of cysts for oceanic species, or for under-thermocline habitats, where slow processes and apparent constant conditions are punctuated by episodic events (Smith, 1994). Recently, Penna and Magnani (1999) assayed rDNA targeted probes to identify Alexandrium species which cause harmful algal blooms (HAB; Han and Terazaki, 1993; Hallegraeff et al., 1998); Bolch (2001) amplified rDNA sequences of some dinoflagellate species from single cysts; Okazaki et al. (2001) produced a monoclonal antibody to assess $S$. trochoidea cyst abundance in muddy bottom sediments. Therefore, an integrated approach using emerging techniques such as molecular ones together with detailed oceanographical data on water mass movements at different scales can strongly contribute to monitoring and investigating taxonomy, dispersal potential, and population dynamics of existing dinoflagellates in the Mediterranean Sea.

\section{ACKNOWLEDGEMENTS}

This work partly fulfils the fellowship activity of L. Della Tommasa in the framework of INTERREG II Italy-Greece project, Axis 5, Measure 5.2, Museo dell'Ambiente research topic. This research was supported by Italian Ministry of University and Research (MIUR), COFIN Projects.

\section{REFERENCES}

Anderson, D. M., J.J. Lively, E.M. Reardon and C.A. Price. - 1985. Sinking characteristics of dinoflagellate cysts. Limnol. Oceanogr., 30(5): 1000-1009.

Belmonte, G., P. Castello, M.R. Piccinni, S. Quarta, F. Rubino, S. Geraci and F. Boero. - 1995. Resting stages in marine sediments off the Italian coast. In: A. Elefteriou, A.D. Ansel and C.J. Smith (eds): Biology and ecology of shallow coastal waters, pp. 53-58. Olsen and Olsen, Fredensborg.

Boero, F. - 1994. Fluctuations and variations in coastal marine environments. P.S.Z.N.I: Mar. Ecol., 15: 3-25.

Boero, F., G. Belmonte, G. Fanelli, S. Piraino and F. Rubino. 1996. The continuity of living matter and the discontinuities of its constituents: do plankton and benthos really exist? Trends Ecol. Evol., 11(4): 177-180.

Bolch, C.J. - 2001. PCR protocols for genetic identification of dinoflagellates directly from single cysts and plankton cells. Phycologia, 40(2): 162-167.

Bolch, C.J. and G.M. Hallegraeff. - 1990. Dinoflagellate cysts in recent marine sediments from Tasmania, Australia. Bot. Mar., 33: $173-192$

Bros, W.E. and B.C. Cowell. - 1987. A technique for optimizing sample size replication. J. Exp. Mar. Biol. Ecol., 114: 63-71.

Carlton, J.T. and J.B. Geller. - 1993. Ecological roulette: the global transport of nonindigenous marine organisms. Science, 261(5117): 78-82.

Dale, B. - 1983. Dinoflagellate resting cysts: "benthic plankton". In: G.A. Fryxell (ed.), Survival Strategies of the Algae, pp. 69136. Cambridge University Press, New York.

Dale, B. - 1996. Dinoflagellate cyst ecology: modeling and ecological applications. In: J. Jansonius and D.C. McGregor (eds.), Palynology: principles and applications, 3: 1249-1275. American Association of Stratigraphic Palynologists Foundation.

Dale, B. - 2001. Marine dinoflagellate cysts as indicators of eutrophication and industrial pollution: a discussion. Sci. Tot. Env., 264 (3): 235-240.

Dale, B. and A.L. Dale. - 1992. Dinoflagellate contribution to the deep sea. Ocean Biocenosis Series ${ }^{\circ}{ }^{5}$. Woods Hole Oceanographic Institution, Woods Hole.

Dale, B., M. Montresor, A. Zingone and K. Zonneveld. - 1993. The cyst-motile stage relationship of the dinoflagellates Diplopelta symmetrica and Diplopsalopsis latipeltata. Eur. J. Phycol., 28: 129-137.

Dale, B., T.A. Thorsen and A. Fjellsa. - 1999. Dinoflagellate cysts as indicators of cultural eutrophication in the Oslofjord, Norway. Estuar. Coast. Shelf Sci., 48: 371-382.

Della Tommasa, L., G. Belmonte, A. Palanques, P. Puig and F. Boero. - 2000. Resting stages in a submarine canyon: a component of shallow-deep sea coupling? Hydrobiologia, 440: 249260.

Ellegaard, M. and Y. Oshima. - 1998. Gymnodinium nolleri Ellegaard et Moestrup sp. ined. (Dinophyceae) from Danish waters, a new species producing Gymnodinium catenatum-like cysts: molecular and toxicological comparison with Australian and Spanish strains of Gymnodinium catenatum. Phycologia, 37(5): 369-378.

Hallegraeff, G.M. - 1998. Transport of toxic dinoflagellates via ships' ballast water: bioeconomic risk assessment and efficacy of possible ballast water management strategies. Mar. Ecol. Prog. Ser., 168: 297-309.

Hallegraeff, G.M. and C.J. Bolch. - 1992. Transport of diatom and dinoflagellate resting spores in ships' ballast water: implications for plankton biogeography and aquaculture. J. Plankton Res., 14: 1067-1084.

Hallegraeff, G.M., J.A. Marshall, J. Valentine and S. Hardiman. 1998. Short cyst-dormancy period of an Australian isolate of the toxic dinoflagellate Alexandrium catenella. Mar. Freshwater Res., 49: 415-420.

Hamer, J.P., T.A. McCollin and I.A.N. Lucas. - 2000. Dinoflagellate cysts in ballast tank sediments: between tank variability. Mar. Pollut. Bull., 40(9): 731-733.

Han, M.-S. and M. Terazaki. - 1993. A toxic dinoflagellate bloom of Alexandrium tamarense (Lebour) Balech in Tokio Bay. $J$. Plankton Res., 12(15): 1425-1428.

Harland, R. - 1982. A review of recent and quaternary organicwalled dinoflagellate cysts of the genus Protoperidinium. Palaeontology, 25(2): 369-397.

Harland, R. - 1983. Dinoflagellates cysts in bottom sediments from the North Atlantic Ocean and adjacent seas. Palaeontology, 26(2): 321-387.

Ishikawa, A. and A. Taniguchi. - 1996. Contribution of benthic cysts to the population dynamics of Scrippsiella spp. (Dinophyceae) in Onagawa Bay, northeast Japan. Mar. Ecol. Prog. Ser., 140: 169-178.

Janofske, D. - 1996. Ultrastructure types in Recent "calcispheres". Bull. Inst. Océanogr. Monaco, 14: 295-303.

Janofske, D. - 2000. Scrippsiella trochoidea and Scrippsiella regalis, nov. comb. (Peridiniales, Dinophyceae): a comparison. J. Phycol., 36(1): 178-189.

Janofske, D. and B. Karwath - 2000. Oceanic calcareous dinoflagellates of the equatorial Atlantic Ocean: cyst-theca relationship, taxonomy and aspects on ecology. Ber. FB Geowiss. Univ. Bremen, 152: 94-133.

Kamiyama, T. - 1996. Determination of the abundance of viable tintinnid cysts in marine sediments in Hiroshima Bay, the Seto Inland Sea of Japan, using a modified MPN method. J. Plankton Res., 18(7): 1253-1259. 
Kasahara, S., S. Uye and T. Onbè - 1974. Calanoid copepods eggs in sea bottom-muds. Mar. Biol., 26: 167-171.

Kerntopf, B. - 1997. Dinoflagellate distribution patterns and preservation in the Equatorial Atlantic and offshore North-West Africa. Ber. FB Geowiss. Univ. Bremen, 103: $136 \mathrm{pp}$.

Lewis, J. - 1990. The cyst-theca relationship of Oblea rotunda (Diplopsalidaceae, Dinophyceae). Br. phycol. J., 25: 339-351.

Lewis, J. - 1991. Cyst-theca relationship in Scrippsiella (Dinophyceae) and related Orthoperidinioid genera. Bot. Mar., 34: 91-106.

Lewis, J., J.D. Dodge and P. Tett - 1984. Cyst-theca relationship in some Protoperidinium species (Peridiniales) from Scottish sea lochs. J. Micropalaeontol., 3(2): 25-34.

Lindley, J.A. - 1990. Distribution of overwintering calanoid copepod eggs in sea-bed sediments around southern Britain. Mar. Biol., 104: 209-217.

Mackenzie, L., D. White, Y. Oshima and J. Kapa. - 1996. The resting cyst and toxicity of Alexandrium ostenfeldii (Dinophyceae) in New Zealand. Phycologia, 35(2): 148-155.

Marcus, N.H. - 1995. Seasonal study of planktonic copepods and their benthic resting eggs in northern California coastal waters. Mar. Biol., 123: 459-465.

Marcus, N.H. and F. Boero. - 1998. Minireview: the importance of benthic-pelagic coupling and the forgotten role of life cycles in coastal aquatic systems. Limnol. Oceanogr., 43 (5): 763-768.

Marret, F. - 1994. Distribution of dinoflagellate cysts in recent marine sediments from the east Equatorial Atlantic (Gulf of Guinea). Rev. Palaeobot. Palynol., 84: 1-22.

Matsuoka, K. - 1988. Cyst-theca relationships in the diplopsalid group (Peridiniales, Dinophyceae). Rev. Palaeobot. Palynol., 56: $95-122$.

Matsuoka, K. - 2001. Further evidence for a marine dinoflagellate cyst as an indicator of eutrophication in Yokohama Port, Tokyo Bay, Japan. Comments on a discussion by B. Dale. Sci. Tot. Env., 264: 221-233.

Matsuoka, K. and H.-J. Cho - 2000. Morphological variation in cysts of the gymnodinialean dinoflagellate Polykrikos. Micropaleontology, 46(4): 360-364.

Matsuoka, K. and Y. Fukuyo - 1994. Geographical distribution of the toxic dinoflagellate Gymnodinium catenatum Graham in Japanese coastal waters. Bot. Mar., 37: 495-503.

Mauchline, J. - 1998. The biology of calanoid copepods. Adv. Mar. Biol., 33: 268-272.

Mc Quoid, M.R. and L.A. Hobson - 1995. Importance of resting stages in diatom seasonal succession. J. Phycol., 31: 44-50.

Mc Quoid, M.R. and L.A. Hobson - 1996. Diatom resting stages. J. Phycol., 32: 889-902.

Meier, K.J.S., D. Janofske and H. Willems. - 2002. New calcareous dinoflagellates (Calciodinelloideae) from the Mediterranean Sea. J. Phycol., 38: 602-615.

Montresor, M. and A. Zingone. - 1988. Scrippsiella precaria sp. nov. (Dinophyceae), a marine dinoflagellate from the Gulf of Naples. Phycologia, 27(3): 387-394.

Montresor, M., A. Zingone and D. Sarno. - 1998. Dinoflagellate cyst production at a coastal Mediterranean site. J. Plankton Res., 20 (12): 2291-2312.

Nehring, S. - 1997. Dinoflagellate resting cysts from recent German coastal sediments. Bot. Mar., 40: 307-324.

Onbé, T. - 1991. Some aspects of the biology of resting eggs of marine cladocerans. In: Wenner, A. and A. Kuris (eds.), Crustacean egg production, A.A. Belkema., pp. 41-55.

Okazaki, K., T. Iwaoka, N. Murakami, I. Kazuhiko and S. Montani.
- 2001. Production of monoclonal antibody against Scrippsiella trochoidea cysts and its application to analysis during cyst formation and enzyme-linked immunosorbent assay. Biosci. Biotechnol. Biochem., 65(2): 470-473.

Pati, A.C., G. Belmonte, V.U. Ceccherelli and F. Boero. - 1999. The inactive temporary component: an unexplored fraction of meiobenthos. Mar. Biol., 134: 419-427.

Penna, A. and M. Magnani. - 1999. Identification of Alexandrium (Dinophyceae) species using PCR and rDNA-targeted probes. J. Phycol., 35: 615-621.

Persson, A., A. Godhe and B. Karlson. - 2000. Dinoflagellate cysts in recent sediments from the West Coast of Sweden. Bot. Mar., 43: 69-79.

Philippi, T. and J. Seger. - 1989. Hedging one's evolutionary bets, revisited. Trends Ecol. Evol., 4(2): 41-44.

Reid, P.C. and A.W.G. John. - 1978. Tintinnid cysts. J. Mar. Biol. Ass. U.K., 58: 551-557.

Rigby, G. and G.M. Hallegraeff - 1996. Ballast water controls to minimise the translocation and establishment of toxic marine phytoplankton - what progress have we made and where we going? In: T. Yasumoto et al. (eds.), Harmful and Toxic Algal Blooms, pp. 201-204.

Rubino, F., G. Belmonte, A.M. Miglietta, S. Geraci and F. Boero. 2000. Resting stages of plankton in recent North Adriatic sediments. P.S.Z.N.I: Mar. Ecol., 21(3-4): 263-286.

Smith, C.R. - 1994. Tempo and mode in deep-sea benthic ecology: punctuated equilibrium revisited. Palaios, 9: 3-13.

Sonneman, J.A. and D.R.A. Hill. - 1997. A taxonomic survey of cyst-producing dinoflagellates from recent sediments of Victorian coastal waters, Australia. Bot. Mar., 40: 149-177.

Uye, S.-I. - 1985. Resting egg production as a life history strategy of marine planktonic copepods. Bull. Mar. Sci., 37(2): 440-449.

Versteegh, G.J.M. - 1993. New Pliocene and Pleistocene calcareous dinoflagellate cysts from southern Italy and Crete. Rev. Palaeobot. Palynol., 78: 353-380.

Vink, A., K.A.F. Zonneveld and H. Willems. - 2000a. Distributions of calcareous dinoflagellate cysts in surface sediments of the western equatorial Atlantic Ocean, and their potential use in palaeoceanography. Mar. Micropaleontol., 38: 149-180.

Vink, A., K.A.F. Zonneveld and H. Willems. - 2000b. Organicwalled dinoflagellate cysts in western equatorial Atlantic surface sediments: distributions and their relation to environment. Rev. Palaeobot. Palynol., 112: 247-286.

Wall, D. and B. Dale. - 1968. Modern dinoflagellate cysts and evolution of the peridiniales. Micropaleontology, 14(3): 265-304.

Wall, D., B. Dale and K. Harada. - 1973. Descriptions of new fossil dinoflagellates from the Late Quaternary of the Black Sea. Micropaleontology, 19: 18-31.

Wall, D., B. Dale, G.P. Lohmann and W.K. Smith. - 1977. The environmental and climatic distribution of dinoflagellate cysts in modern marine sediments from regions in the North and South Atlantic Oceans and adjacent seas. Mar. Micropaleontol., 2: 121-200.

Zonneveld, K.A.F. - 1995. Palaeoclimatic and palaeoecological changes during the last deglaciation in the Eastern Mediterranean - implications for dinoflagellate ecology. Rev. Palaeobot. Palynol. 84: 221-253.

Zonneveld, K.A.F. and G.J.A. Brummer. - 2000. (Palaeo-)ecological significance, transport and preservation of organic-walled dinoflagellate cysts in the Somali Basin, NW Arabian Sea. Deep-Sea Res. II, 47: 2229-2256. 